\title{
High levels of gene flow and low population genetic structure related to high dispersal potential of a tropical marine angiosperm
}

\author{
Jent Kornelis van Dijk ${ }^{1}$, Brigitta I. van Tussenbroek ${ }^{1, *}$, Karina Jiménez-Durán², \\ G. Judith Márquez-Guzmán², Joop Ouborg ${ }^{3}$ \\ ${ }^{1}$ Unidad Académica Puerto Morelos, Instituto de Ciencias del Mar y Limnología, Universidad Nacional Autónoma de México \\ (UNAM), Apdo. Postal 1152, Cancún 77500, Quintana Roo, México \\ ${ }^{2}$ Laboratorio de Desarrollo de Plantas, Facultad de Ciencias, UNAM, Circuito Exterior, Ciudad Universitaria, Del. Coyoacán, \\ México D.F. 04510, México \\ ${ }^{3}$ Department of Ecology, Radboud University Nijmegen, Tournooiveld 1, 6525 ED Nijmegen, The Netherlands
}

\begin{abstract}
Marine ecosystems are traditionally considered to be highly connected, caused by longdistance movements of propagules in an open fluid medium. But this principle is not universal, and populations of many marine organisms have restricted gene-flow, including ones with drifting propagules. Direct tracking of marine free-floating propagules over large distances is virtually impossible, but long-distance dispersal (LDD) can be deduced from their drifting time and transport rates. Alternatively, LDD can be estimated as genetic exchange with the use of allelic frequency data obtained with genetic markers. The present study compares both approaches of LDD estimation for the tropical seagrass Thalassia testudinum. Fruit dispersal potential was measured in Puerto Morelos reef lagoon, Mexico. Between 10 and $15 \%$ of the fruits floated to the surface (floating potential $<1$ to $10 \mathrm{~d}$ ), with a derived potential dispersal of $<1$ to $360 \mathrm{~km}$. The remainder of the fruits dehisced in situ followed by limited seed dispersal $(<1$ to $10 \mathrm{~m})$. Genetic diversity was characterized using 6 microsatellite loci for 16 populations distributed along a $1350 \mathrm{~km}$ long stretch of the Mexican coast, revealing a total of 58 alleles. AMOVA showed that only $9.75 \%$ of the total variation was accounted for by genetic differences between the populations. Isolation by distance was significant, and revealed a panmictic area of $350 \mathrm{~km}$. The results of both approaches of LDD estimation coincided well and the maximum displacement of the fruits of this marine angiosperm exceeded, by 1 to 2 orders of magnitude, the reported seed dispersal by terrestrial seed plants.
\end{abstract}

KEY WORDS: Connectivity · Genetic diversity $\cdot$ Fruit buoyancy $\cdot$ Hydrochory $\cdot$ Isolation by distance - Microsatellite markers $\cdot$ Long-distance dispersal $\cdot$ Seagrass $\cdot$ Thalassia testudinum

\section{INTRODUCTION}

In the marine environment, the life cycle of many sessile or sedentary organisms includes a planktonic or free-floating phase, which allows for transport of progeny outside the donor population (Roughgarden et al. 1988, Siegel et al. 2003). Such free-living propagules of either plants or animals may be larvae, eggs, gametes, spores, rafting vegetative or reproductive plant fragments or seeds (Harwell \& Orth 2002, Kinlan \& Gaines
2003, Källström et al. 2008). Due to the fluid characteristics of the marine environment, long-distance dispersal (LDD) by oceanic currents is a likely scenario, and in general, the dispersal capacity of the free-living propagules of marine species is thought to be high. Therefore, marine populations, in comparison to terrestrial ones, are hypothesized to be more open with greater dispersal potentials (Carr et al. 2003, Kinlan \& Gaines 2003, Kinlan et al. 2005). In specific cases, LDD may be important for the survival, establishment and 
local adaptation of spatially distributed populations (Dieckmann et al. 1999, Harwell \& Orth 2002, Largier 2003). But in general, LDD is infrequent and stochastic and plays a role in processes with longer evolutionary time scales, such as genetic population connectivity, community responses to climate change, metapopulation dynamics, large-scale disturbance and speciation (Dieckmann et al. 1999, Cain et al. 2000, Kinlan et al. 2005, Procaccini et al. 2007). At present, knowledge of marine connectivity is essential for the design and establishment of marine reserve networks which, in the case of sessile organisms, are connected through transfer of their free-living propagules (Leslie et al. 2003, Palumbi 2003, Shanks et al. 2003, Guichard et al. 2004).

However, dispersal distances in the marine environment vary widely, and may differ by several orders of magnitude between or within taxa (Kinlan \& Gaines 2003, Shanks et al. 2003) or species groups occupying a similar ecological niche, such as marine angiosperms or seagrasses. Some seagrasses release their seeds below the sediments, such as Cymodocea spp. and Halodule spp., but almost $50 \%$ of the genera have floating fruits, seeds or inflorescences (Orth et al. 2006). However, the relationship between high or low drifting potential and genetic connectivity between the seagrass populations is not always straightforward (Waycott et al. 2006). For example, Zostera marina has been shown to disperse on the order of $100 \mathrm{~km}$ by dislodged fruit-bearing rhipidia (Harwell \& Orth 2002, Källström et al. 2008), and populations showed high genetic connectivity at an oceanic scale (Reusch 2002, Olsen et al. 2004, Muñiz-Salazar et al. 2005, Ferber et al. 2008), a phenomenon also found for Zostera noltii (Coyer et al. 2004). Contrary to this, Posidonia oceanica has low genetic migration rates, and a clear $\mathrm{E}-\mathrm{W}$ genetic division was found in the Mediterranean (Arnaud-Haond et al. 2007). This restricted gene flow is surprising as this species has large hydrochoric fruits (Buia \& Mazzella 1991). Inconsistent findings between gene flow and modes of propagule dispersal within this ecological group of marine plants emphasizes the importance of both genetic and more direct measurements of dispersal capacity in understanding the biogeographical patterns and genetic structuring of marine populations.

Long-distance movements of marine organisms are virtually impossible to measure directly (Cain et al. 2000, Cowen et al. 2006). Nevertheless, the dispersal kernel of marine sedentary organisms is related to the residence time of their free-living propagules (Nathan \& MullerLandau 2000, Cowen et al. 2006), and can thus be derived from their drifting time and transport rates. But dispersal will only be successful, and genetically detectible, if the release of a propagule is followed by settlement and establishment, also known as effective dispersal (Cain et al. 2000). Population genetics studies determine patterns of fixation of imported genes in the populations over many generations, thus indicating effective marine dispersal patterns (Maguire et al. 2000, Núñez-Farfán et al. 2002, Olsen et al. 2004).

The present study aims to compare direct estimates of the dispersal potential of the floating fruits of the dioecious marine angiosperm Thalassia testudinum with models of genetic structuring and genetic connectivity. The tropical Atlantic coast of Mexico presents a long stretch of coastline $(\sim 1350 \mathrm{~km})$ bordered by almost uninterrupted $T$. testudinum beds. In contrast to islands or isolated populations interrupted by large stretches of unsuitable habitat, the more or less continuous vegetated coastline permits a uniform distribution of suitable sites for seed establishment, and therefore provides an ideal setting for the testing of models of marine dispersal.

\section{MATERIALS AND METHODS}

Study region. Study sites were located along the tropical Atlantic coast of Mexico, which borders the Caribbean Sea and the Gulf of Mexico (Fig. 1). The Caribbean coastline is protected by the Mesoamerican Barrier Reef System. The Gulf of Mexico populations were situated at the coastal edge of a shallow, 37 to $220 \mathrm{~km}$ broad continental shelf (Hernández-Arana et al. 2003), where lower hydrodynamic regimes allow the development of extensive coastal seagrass beds. Surface rivers are absent in this karstic limestone platform of the Yucatan Peninsula. In the state of Tabasco, high hydrodynamic coastal regimes and the Grijalva watershed inhibit the development of coastal Thalassia testudinum beds (Onuf et al. 2003), separating the Veracruz population from the other study sites.

The assessment of the dispersal capacity of Thalassia testudinum fruits was assessed in the Puerto Morelos reef lagoon, Mexico ( $20^{\circ} 51^{\prime} \mathrm{N}, 86^{\circ} 55^{\prime} \mathrm{W}$ ), which is bordered on the seaward site by a fringing reef between 500 and $1800 \mathrm{~m}$ from the coast. Within this reef lagoon, average currents vary between 10 and $20 \mathrm{~cm} \mathrm{~s}^{-1}$, their direction generally being from $\mathrm{S}$ to $\mathrm{N}$ parallel to the coast, although they may invert at times (Coronado et al. 2007). A well-developed seagrass community, dominated by $T$. testudinum, covers the coarse calcareous sands in this reef lagoon (van Tussenbroek 1995, RuízRentería et al. 1998).

Fruit dispersal. The frequency of fruit detachment was determined during the 2003 fruiting season at the stations Mid-lagoon $1\left(20^{\circ} 52.224^{\prime} \mathrm{N}, 86^{\circ} 51.472^{\prime} \mathrm{W}\right)$, Mid-lagoon $2\left(20^{\circ} 52.248^{\prime} \mathrm{N}, 86^{\circ} 51.346^{\prime} \mathrm{W}\right)$ and Backreef $\left(20^{\circ} 51.787^{\prime} \mathrm{N}, 86^{\circ} 51.503^{\prime} \mathrm{W}\right)$, in the Puerto Morelos reef lagoon. At each site, 40 large mature fruits 


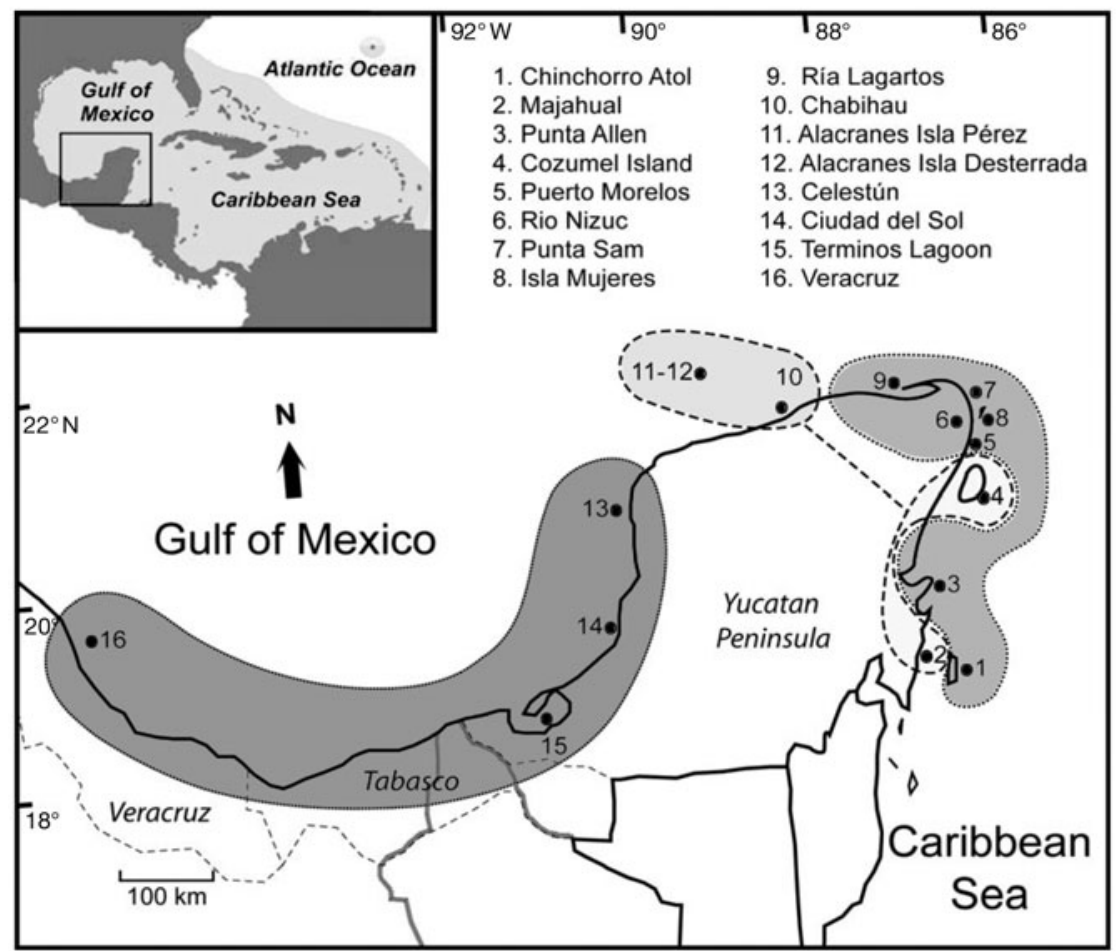

Fig. 1. Thalassia testudinum. Sampled populations along the Atlantic coast of Mexico, showing the distribution of the 3 genetic population clusters (indicated by grey shading) determined with STRUCTURE (Pritchard \& Wen 2003), and based on the highest membership proportions from Table 4. The light grey area of the inset map indicates the distribution area of $T$. testudinum

(1.4 to $2.6 \mathrm{~cm}$ diameter) attached to the mother plant were marked and were inspected every 2 to $4 \mathrm{~d}$ to observe whether they had detached or had opened in situ, indicated by an open pericarp still attached to the mother shoot. This was repeated on 6 occasions (see Table 1), and the inspections continued until no unopened fruit remained in the area. In 2004, the frequency of fruit detachment was determined, employing a vertical (static) instead of horizontal (dynamic) approach at the back-reef site. On 5 occasions in August and September 2004, between 78 and 84 mature fruits were marked and the number of dehisced or detached fruits was recorded after 6 to $7 \mathrm{~d}$.

To determine the flotation time, collected ripe fruits were placed in sea cages of plastic mesh $(0.7 \mathrm{~m}$ diameter, $1 \mathrm{~m}$ height $)$ or in marine tanks $\left(216 \times 10^{3} \mathrm{l}\right)$ until dehiscence. During September and October, we performed 6 trials in the tanks and 3 in the sea cages, using 20 fruits per trial. A chi-squared $\left(\chi^{2}\right)$ test was applied to the pooled data per treatment (sea cage or tank) to verify whether the number of dehisced fruits per day was independent of treatment.

Five field simulations of fruit dispersal were performed in September 2002 and October 2003 (see Table 2). Orange bouncing balls were used as physical models of the fruits, resembling the latter in form, size and density. Density of the models and fruits was veri- fied from determination of their fresh weight and volume displacement in $20^{\circ} \mathrm{C}$ distilled water. The field simulation consisted of releasing 50 models at a fixed point and following their trajectory at $\sim 100 \mathrm{~m}$ distance by boat during 1.5 to $2 \mathrm{~h}$. At intervals of 20 to $30 \mathrm{~min}$, the 2 extremes of the dispersal plume were marked with a GPS (Magellan 315) by free divers. The mean of these coordinates was considered for the calculation of speed and direction of displacement of the models. Simultaneously, a neutral drifting body consisting of an underwater sail $(2 \times 1 \mathrm{~m})$ was released and followed to determine speed and direction of the superficial current. During the first simulation, 50 real fruits were also released to verify whether the models showed similar dispersal patterns to the fruits. Wind velocity and direction during the trials were obtained from an automatic meteorological station (Hydrographic and Meteorological Service, Unidad Académica Puerto Morelos, unpubl. data).

Population genetics. Along the east coast of Mexico, 16 populations were studied; the distance between neighboring populations differed between 7 and $460 \mathrm{~km}$ (Fig. 1). The sampling sites consisted of extensive near-coastal Thalassia testudinum beds, between 30 and $200 \mathrm{~m}$ from the shore, at 0.5 to $1.5 \mathrm{~m}$ depth. At each site, a total of 36 shoots were collected at intervals of 1 to $25 \mathrm{~m}$ along a $\sim 230 \mathrm{~m}$ linear transect, parallel to 
the coast. Within $1 \mathrm{~h}$ after sampling, a $\sim 2 \mathrm{~cm}$ long fragment of the basal sheath tissue of the shoots was preserved in tubes with silica gel. In the present study we refer to a shoot (vertical rhizome with leaves) as a ramet. Ramets that are interconnected by the horizontal rhizome are considered to be a clone, and a genetically unique individual that originated from one zygote is a genet.

In the laboratory, DNA was extracted from rehydrated samples following Doyle \& Doyle (1991) with few modifications. The DNA was diluted to a 10 to $20 \mu \mathrm{g} \mathrm{ll}^{-1}$ concentration for amplification with PCR using 6 microsatellite primer pairs (TTMS-GA6, TTMS-GA8，TTMS-TGA39，TTMS-TCT58，TTMSGGT59, TTMS-GT112) following the conditions described by van Dijk et al. (2007). PCRs in $20 \mu \mathrm{l}$ reactions were performed on a Flexigene thermocycler $\left(\mathrm{Techne}^{\mathrm{TM}}\right)$ using 96 tube plates. On each plate, the last tube contained the original enriched microsatellite vector DNA, which served as a reference for the genotyping. The denaturized PCR products were loaded on a $38 \times 50 \mathrm{~cm}, 4 \mathrm{~mm}, 6 \%$ polyacrylamide gel with $7 \mathrm{M}$ Urea - Sequigen GT System (Biorad) for separation. Vector DNA amplicons and a 10 bp DNA ladder (Invitrogen) were used for size determination. All gels were silver stained using the slightly modified protocol of Creste et al. (2001), and bands were sized using a white light trans-illuminator.

Genetically identical ramets were identified with the software program GenClone 2.0 (Arnaud-Haond \& Belkhir 2007), as was the total number of unique genets in each population. The probability of clonal identity based on allele frequencies was calculated according to Parks \& Werth (1993). Subsequent analyses were only applied to the genets. Calculation of allele frequencies, observed heterozygosity $\left(H_{O}\right)$. Expected heterozygosity or Nei's gene diversity $H_{\mathrm{E}}$ (Nei 1973), average number of alleles $(A)$ and an analysis of molecular variance (AMOVA, 1000 permutations) was performed with ARLEQUIN v.3.1 (Excoffier et al. 2005). The GENEPOP web version (Goudet 1995, 2002, Raymond \& Rousset 1995) was used to estimate the inbreeding coefficient $\left(F_{\mathrm{IS}}\right)$ per population (Weir \& Cockerham 1984), applying 2000 permutations. Normal distribution of gene frequencies of each locus was tested with a Shapiro-Wilk test using Analyse-it v.1.73 (www.analyse-it.com). The average allelic richness per locus $\left(\mathrm{R}_{\mathrm{t}}\right)$ was determined with the use of HP-RARE (Kalinowski 2005) after rarefaction to 15 samples; this because of the unequal number of genets per population due to the high clonality in some populations of this species (see Table 3).

Regional genetic structure and genetic connectivity were determined with 3 analytical procedures. A regression of the pairwise genetic distances between populations of Rousset (1997) vs. pairwise geographical distances was plotted, and the significance of the relationship was calculated with a Mantel test. The Mantel test was performed with IBD 1.52 (Bohonak 2002) with 10000 randomizations, using the shortest possible distance over sea between sites. A reduced major axis regression was used to determine slope, intercept and p-value of the IBD graph. A Bayesian assignment procedure (STRUCTURE v.2.1, Pritchard \& Wen 2003) was used to determine the optimal number of genetic clusters $(K)$, with $K$-values initially set from 1 to 16 with an initial burn-in length of $10^{5}$, followed by a run length of $10^{6}$ assuming admixture and correlated allele frequencies (due to probable high migration rates). The true number of clusters was corroborated employing the $\Delta \mathrm{K}$ statistic following Evanno et al. (2005) by repeating 20 independent runs. Finally, evidence of recent migration rates between populations was determined with a Bayesian assessment procedure integrated in the software BayesAss v.1.3, using a Markov chain Monte Carlo algorithm (Wilson \& Rannala 2003), applying the program default settings.

\section{RESULTS}

\section{Fruit dispersal}

On average, 10.2 and $15.2 \%$ of fruits detached and floated to the surface in 2003 and 2004, respectively (excluding the observations on 22 September 2004, see Table 1). A small percentage was eaten, which was noted by bite marks in the pericarps. No considerable differences in the proportion of detached fruits were detected between sites in 2003 (Table 1). The time the fruits remained intact and afloat was similar for those placed in the sea cages or tanks, the $\chi^{2}$ of independence being 3.82 (df 9, $0.9<\mathrm{p}<0.95$, Fig. 2). More than half $(52.5 \%)$ of the fruits had dehisced and released their seeds within $1 \mathrm{~d}$. After the first day, the rates of fruit dehiscence followed by seed release decreased, and fruits stayed afloat for up to $10 \mathrm{~d}$ (Fig. 2).

Displacement of the fruits and models was similar (Table 2), and further observations were realized with models only. Vector conversions of the models and the drifting body displacement allowed derivation of the effect of wind on the displacement of the models (Fig. 3). The effect of wind on fruit displacement was approximately $10 \%$ of its velocity, and roughly (although not completely) coincided with its direction (Table 2). In the Puerto Morelos reef lagoon, the mean velocity of the floating fruits from all experiments was $395 \mathrm{~m} \mathrm{~h}^{-1}\left(9.48 \mathrm{~km} \mathrm{~d}^{-1}\right)$, and the estimated potential transport of fruits, based on this transport rate and floating capacity, is presented in Fig. 4. During the last 
Table 1. Thalassia testudinum. Fate of marked mature T. testudinum fruits in the Puerto Morelos reef lagoon, Mexico. D: date; $\mathrm{N}$ : number of fruits; bitten: fruits with bite marks in the pericarp; complete: fruits that remained intact over the observation period in 2004. Fruits opened in situ (open) had a disintegrated pericarp, detached fruits had only a pedicel. nr: not relevant; nd: not determined. *: Hurricane Ivan passed with tropical storm strength on 13 September 2004

\begin{tabular}{|c|c|c|c|c|c|c|c|c|}
\hline \multirow[t]{2}{*}{ Site (year) } & \multirow[t]{2}{*}{$\mathrm{D}_{\text {initial }}$} & \multirow[t]{2}{*}{$\mathrm{D}_{\text {final }}$} & \multirow{2}{*}{$\begin{array}{l}\text { Interval } \\
\text { (d) }\end{array}$} & \multirow[t]{2}{*}{$\mathrm{N}_{\text {bitten }}$} & \multirow[t]{2}{*}{$\mathrm{N}_{\text {complete }}$} & \multirow[t]{2}{*}{$\mathrm{N}_{\text {analysed }}$} & \multicolumn{2}{|c|}{$\%$ fruits } \\
\hline & & & & & & & Open & Detached \\
\hline \multirow[t]{3}{*}{ Mid-lagoon 1 (2003) } & $18 \mathrm{Aug}$ & $08 \mathrm{Sep}$ & $2-4$ & 0 & $\mathrm{nr}$ & 40 & 92.5 & 7.5 \\
\hline & $01 \mathrm{Sep}$ & 26 Sep & $2-4$ & 0 & $\mathrm{nr}$ & 40 & 82.5 & 17.5 \\
\hline & 22 Sep & 13 Oct & $2-4$ & 3 & $\mathrm{nr}$ & 37 & 89.2 & 10.8 \\
\hline Mid-lagoon 2 (2003) & $22 \mathrm{Sep}$ & 14 Oct & $2-4$ & 1 & $\mathrm{nr}$ & 39 & 89.7 & 10.3 \\
\hline \multirow[t]{3}{*}{ Back-reef (2003) } & 20 Aug & 29 Sep & $2-4$ & 0 & $\mathrm{nr}$ & 40 & 90.0 & 10.0 \\
\hline & 04 Sep & $10 \mathrm{Oct}$ & $2-4$ & 1 & $\mathrm{nr}$ & 39 & 92.3 & 7.7 \\
\hline & $19 \mathrm{Sept}$ & 13 Oct & $2-4$ & 5 & $\mathrm{nr}$ & 35 & 91.4 & 8.6 \\
\hline \multirow[t]{5}{*}{ Back-reef (2004) } & 12 Aug & 18 Aug & 6 & 3 & 59 & 16 & 87.5 & 12.5 \\
\hline & 18 Aug & 25 Aug & 7 & 4 & 55 & 21 & 85.8 & 14.2 \\
\hline & 25 Aug & 02 Sep & 6 & 6 & 42 & 35 & 80.0 & 20.0 \\
\hline & 02 Sep & 08 Sep & 7 & 2 & 40 & 42 & 85.8 & 14.2 \\
\hline & $08 \mathrm{Sep}^{*}$ & 22 Sep & 14 & nd & 9 & 74 & 35.1 & 64.7 \\
\hline
\end{tabular}

experiment (13 October 2003), the models, released $\sim 50 \mathrm{~m}$ from the reef tract, disappeared from the reef lagoon after 30 min and were lost from sight, and were most likely picked up by stronger coastal currents; their estimated displacement is also depicted in Fig. 4.

\section{Population genetics}

The basic genetic variables of the studied Thalassia testudinum populations are shown in Table 3. None of the populations had unique alleles, but the genets were unique for each population. The majority of the populations did not deviate significantly from HWE, except for Puerto Morelos (heterozygote deficit) and Chabihau (heterozygote excess). All loci in all populations were polymorphic with a total of 58 alleles. The average number of alleles, $A$, per locus ranged between 3.3 (Terminos Lagoon) to 6.5 (Majahual and Punta Allen; Table 3). Allelic diversity curves indicated that a minimum sample size of approximately 15 genets was required to capture the diversity of the loci,

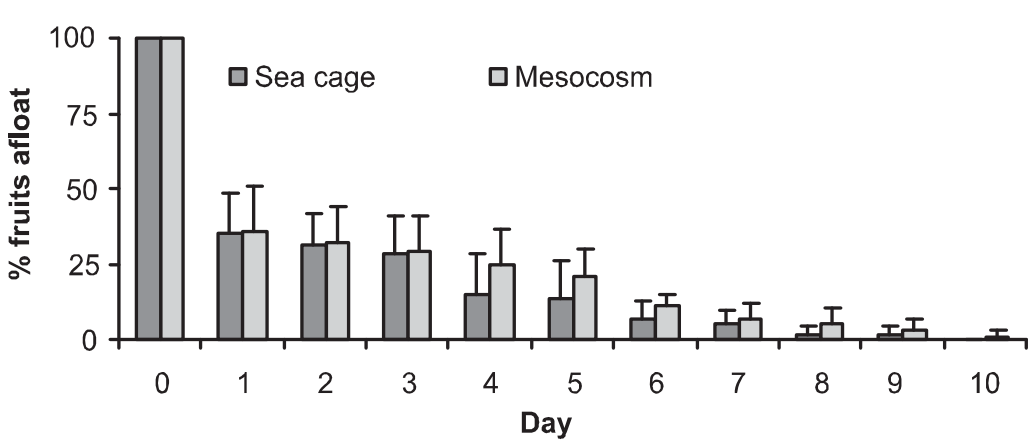

Fig. 2. Thalassia testudinum. Mean percentage of fruits afloat (of a total of 20 fruits) in the experimental sea cages ( 3 trials) and mesocosms ( 5 trials) during September-October 2003. Error bars are +SD which was accomplished for most populations, except for the populations at Ría Lagartos (10 genets), Celestún (4 genets) and Terminos Lagoon (10 genets). $\mathrm{R}_{\mathrm{t}}$ was similar to $A$ and ranged between 3.7 and 5.8. None of the loci had a normal distribution when tested with the Shapiro-Wilk test ( $p<0.0001$ in all cases), thus the Infinite Allele Model (IAM) for microsatellites could be applied. AMOVA analysis revealed that $9.75 \%$ of variance was attributable to genetic variation between the populations and $90.25 \%$ was attributable to genetic variation between the samples within the populations. $F_{\text {ST }}$ over all populations was 0.098 ( $\left.p<0.000\right)$, indicating a low overall population differentiation.

The STRUCTURE v.2.1 analysis showed only slight clustering with low assignment probabilities, revealing 3 clusters. A posteriori probability $\mathrm{P}(K / \mathrm{X})$ for these 3 clusters was of 1.00 , and the a posteriori $\Delta K$ statistic of Evanno et al. (2005) also indicated that $K$ was 3. The clusters were not always tightly coupled to geographical areas (Fig. 1, Table 4), and their probability of assignment to any of the 3 clusters was relatively low $(0.363<\mathrm{p}<0.857$, Table 4$)$. The isolation by distance (IBD) was highly significant (Mantel test, $\mathrm{R}^{2}=0.207$, $\mathrm{p}<0.0024$; Fig. 5). Stepwise regression analysis at geographic distance intervals of $50 \mathrm{~km}$ revealed significant genetic differentiation at distances $>350 \mathrm{~km}$ (at $\alpha=0.05$ ), which could be considered as the approximate area were gene flow prevented genetic differentiation, or the area of panmixis. The migration values into each population (percentage of direct immigrants and the filial generation $\left[F_{1}\right]$ of immigrants with non-immigrants) estimated by Bayesian based assignment tests of 
Table 2. Thalassia testudinum. Dispersal of floating fruits and fruit models in Puerto Morelos reef lagoon. Speed and direction of current from drifting body, wind from an automatic meteorological station (Hydrographic and Meteorological Service, Unidad Académica Puerto Morelos). The vector of wind effect was the resultant vector of the vectors of displacement of the models and drifting body (see Fig. 3). Directions were presented indicating destination, not origin. nd: not determined; na: not applicable. ${ }^{*}$ : Models were lost after 30 min observation, and crossed the reef barrier

\begin{tabular}{|c|c|c|c|c|c|c|c|c|c|c|c|}
\hline \multirow[t]{2}{*}{ Date } & \multirow{2}{*}{ Module } & \multirow[b]{2}{*}{$\begin{array}{l}\text { Distance } \\
\quad(\mathrm{m})\end{array}$} & \multicolumn{2}{|c|}{ Module displacement } & \multirow[b]{2}{*}{$\begin{array}{c}\text { Direction } \\
\quad\left(^{\circ}\right)\end{array}$} & \multicolumn{2}{|c|}{- Current -} & \multicolumn{2}{|c|}{$\longrightarrow$ Wind -} & \multicolumn{2}{|c|}{ Vector wind effect } \\
\hline & & & $\begin{array}{l}\text { Time } \\
\text { (min) }\end{array}$ & $\begin{array}{l}\text { Speed } \\
\left(\mathrm{m} \mathrm{h}^{-1}\right)\end{array}$ & & $\begin{array}{l}\text { Speed } \\
\left(\mathrm{m} \mathrm{h}^{-1}\right)\end{array}$ & $\begin{array}{c}\text { Direction } \\
\left({ }^{\circ}\right)\end{array}$ & $\begin{array}{l}\text { Speed } \\
\left(\mathrm{m} \mathrm{s}^{-1}\right)\end{array}$ & $\begin{array}{c}\text { Direction } \\
\left({ }^{\circ}\right)\end{array}$ & $\begin{array}{l}\text { Speed } \\
\left(\mathrm{m} \mathrm{s}^{-1}\right)\end{array}$ & $\begin{array}{c}\text { Direction } \\
\left({ }^{\circ}\right)\end{array}$ \\
\hline \multirow[t]{2}{*}{06 Sep 2002} & Fruit & 1022 & 138 & 444 & 358 & 353 & 358 & nd & 350 & 0.026 & 354 \\
\hline & Model & 995 & 135 & 443 & 357 & & & & & & \\
\hline 17 Sep 2002 & Model & 789 & 131 & 360 & 343 & 421 & 10 & nd & 245 & 0.053 & 248 \\
\hline 02 Oct 2003 & Model & 641 & 91 & 676 & 326 & 331 & 351 & 5.83 & 290 & 0.051 & 277 \\
\hline 08 Oct 2003 & Model & 563 & 106 & 320 & 330 & 284 & 348 & 5.23 & 292 & 0.048 & 272 \\
\hline 13 Oct 2003 & Model & na* & na & na & na & 36 & 147 & 2.72 & 293 & na & na \\
\hline
\end{tabular}

origin (BayesAss) of each individual are shown in Table 5. Probabilities of the total migration into each population varied between $1.4 \%$ (Alacranes, Isla Pérez) and $31.5 \%$ (Punta Sam). A mean of $83 \%$ of individuals were assigned to their own population (non-immigrants) $(95 \% \mathrm{CI}=68$ to $99 \%)$. Chabihau appeared to be the population that contributed most to the immigration into other populations. Neither the Caribbean nor the Gulf of Mexico populations demonstrated a clear direction in gene flow (Table 5).

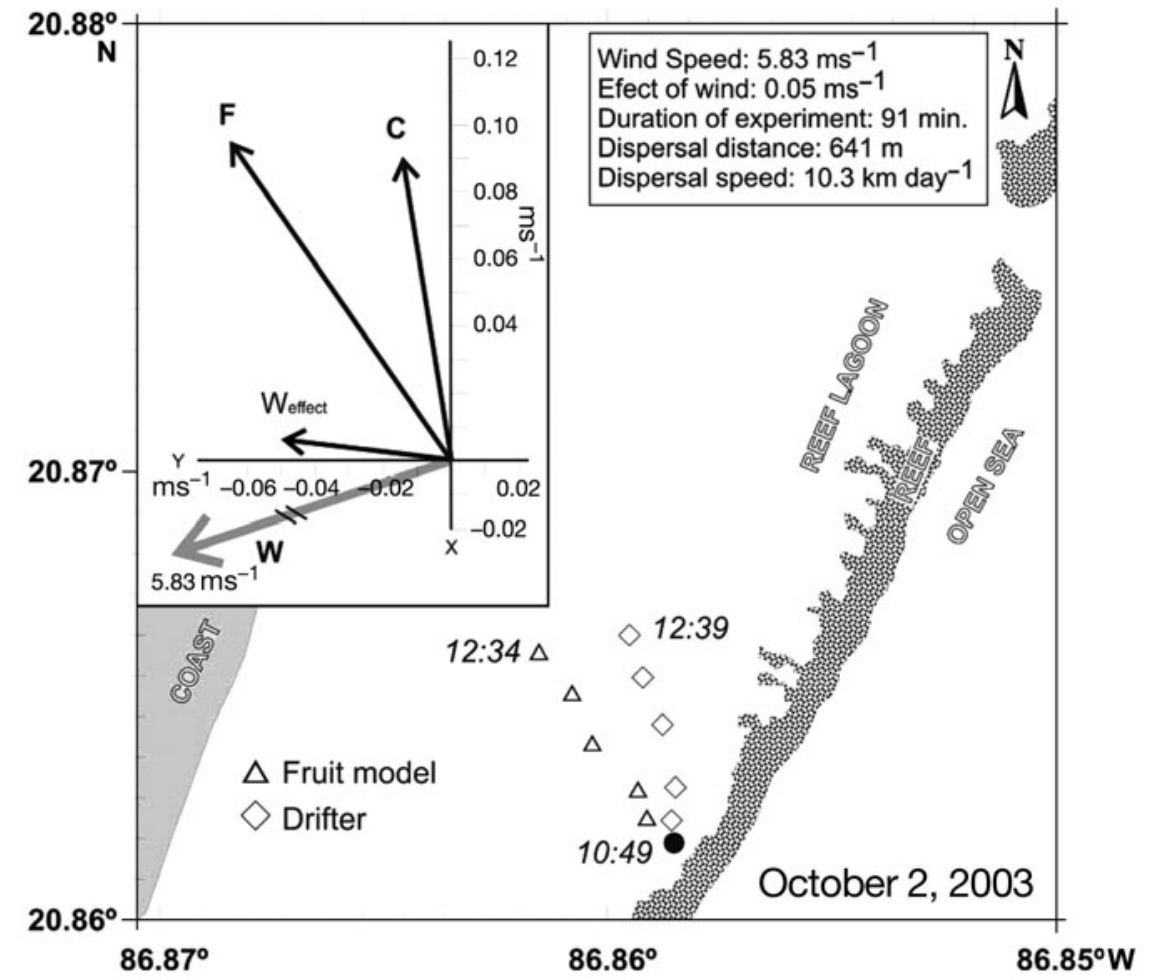

Fig. 3. Thalassia testudinum. Displacement tract of 50 physical fruit models and the neutral drifting body in the Puerto Morelos reef lagoon (trial: 2 October 2003, Table 2). The inset indicates the vector map of the models $(\mathrm{F})$, current $(\mathrm{C})$, wind effect $\left(\mathrm{W}_{\text {effect }}\right)$ and wind $(\mathrm{W})$

\section{DISCUSSION}

The populations of the marine angiosperm Thalassia testudinum distributed along the $\sim 1350 \mathrm{~km}$ stretch of Mexican coastline were highly connected. The distribution of genes was homogeneous, and the AMOVA attributed only $9.2 \%$ of the total genetic variability to variation between the populations, and the resulting $90.8 \%$ to variation of genets within the studied populations. This homogeneous genetic distribution was supported by the low assignment probabilities of the populations into genetic clusters (Table 4), and corresponding poor geographical arrangement of these clusters, with exception of the populations from the southern Gulf of Mexico (Fig. 1). IBD was significant ( $p=0.0024)$, but the fit $\left(R^{2}\right)$ was low, and only $21 \%$ of the variation could be attributed to the geographical separation. Considering that the distribution of suitable habitat for propagule establishment was almost continuous along the Mexican coastline (with the possible exception of Veracruz, the atolls and Cozumel Island), we expected a more defined pattern of IBD. Instead, some distant populations had low differentiation values (e.g. Punta Allen and Chabihau, $F_{\mathrm{ST}}=$ $0.000,94 \mathrm{~km})$, whereas other nearby populations were genetically distinct (e.g. Puerto Morelos and Rio Nizuc, $F_{\mathrm{ST}}=0.127$, $23 \mathrm{~km}$ ). This suggests that gene flow occurred at different scales, indicating haphazard propagule dispersal combined with unequal chances of successful establishment (Ibrahim et al. 1996). Correlations of genetic distance versus geographical distance showed a panmictic unit of 350 $\mathrm{km}$ for $T$. testudinum in the sampled area, 


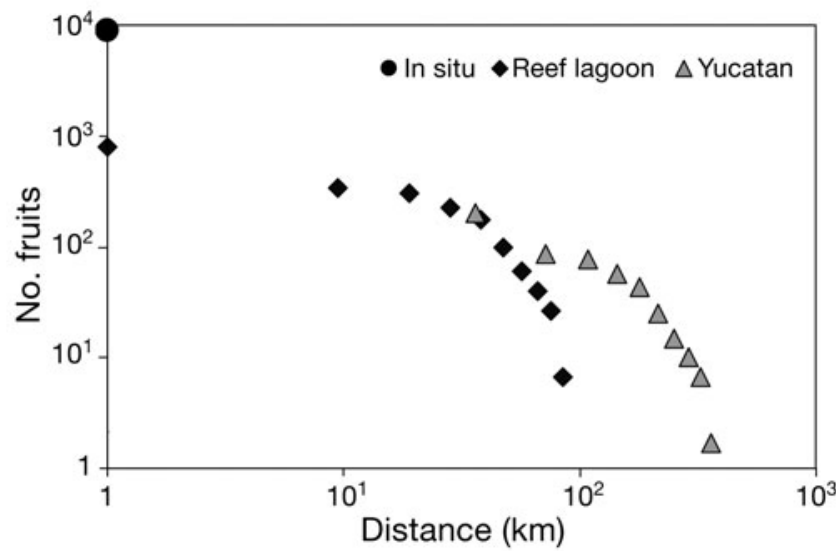

Fig. 4. Thalassia testudinum. Potential coastal dispersal of floating fruits, starting with 10000 fruits (top left; log scale), assuming that $90 \%$ of the fruits dehisced in situ and seed dispersal was limited. Dispersal capacity of the $10 \%$ of the fruits was deduced from the number of fruits afloat after $\mathrm{N}$ days and their estimated displacement. $80 \%$ of fruits remained within the reef lagoon, with a mean displacement of $9.5 \mathrm{~km} \mathrm{~d}^{-1}$ (present study), and $20 \%$ moved outside the lagoon, entering the coastal circulation of the Yucatan Peninsula, with a minimum mean displacement of $36 \mathrm{~km} \mathrm{~d}^{-1}$ (Merino Ibarra 1986)

which was higher than that found for Zostera marina ( 150 km, Reusch 2002, Olsen et al. 2004) and its congener Z. noltii (100 to $150 \mathrm{~km}$, Coyer et al. 2004). The red mangrove Rhizophora mangle, with its hydrochoric viviparous floating fruits, has a somewhat similar dis- persal strategy as T. testudinum. However, high values of genetic differentiation $\left(F_{\mathrm{ST}} \sim 0.25\right.$, allozyme-based analysis on 8 populations) have been reported for this species in the same area as the present study (Núnez Farfán et al. 2002). At present, T. testudinum is the marine angiosperm with the highest level of genetic connectivity. High genetic homogeneity between populations of this seagrass had already been revealed based on randomly amplified polymorphic DNA analysis by Kirsten et al. (1998) in Florida Bay and Larkin et al. (2006) in Laguna Madre, Texas, and amplified fragment length polymorphism fingerprinting exhibited remarkable resemblance between Panamanian and Bermudan populations (Waycott \& Barnes 2001).

The modules of dispersal of Thalassia testudinum are the positively buoyant fruits containing seeds. The transport and establishment of vegetative fragments most likely did not occur or was very infrequent, as no repeated genotypes (genets) were encountered at the distinct sites. Other authors (Kaldy \& Dunton 1999, Orth et al. 2006) have reported that seeds of $T$. testudinum can float for a limited time $(<1 \mathrm{~d})$ when air is trapped under the membrane-like seed coat; however, this rarely occurred in our study area, and was not considered as a dispersal strategy in the present study. Even though the populations of $T$. testudinum along the coasts of Mexico were highly connected, we found that the majority (85 to $90 \%$ ) of the fruits of T. testudinum of the Puerto Morelos reef lagoon dehisced while attached to the mother plant, liberating the seeds

Table 3. Thalassia testudinum. Properties of genetic variability of 16 populations from Mexico. The numbers before the populations correspond with the site numbers from Fig. 1 . N: no. ramets; G: no. genets; $H_{\mathrm{E}}$ : expected heterozygosity; $H_{\mathrm{O}}$ : observed heterozygosity; $F_{\mathrm{IS}}$ : inbreeding coefficient $\left({ }^{*}\right.$ : significant departure from Hardy-Weinberg equilibrium after Bonferroni correction at $\mathrm{p}<0.05) ; A$ : average number of alleles per locus; $\mathrm{R}_{\mathrm{t}(15)}$ : average allelic richness at rarefaction to 15 genets; $-:$ no data $(\mathrm{G}<15) ;$ $p_{\text {gen }}(f)_{\text {max }}$ : maximal probability of clonal identity. Alacranes-IP: Isla Pérez; Alacranes-ID: Isla Desterrada

\begin{tabular}{|c|c|c|c|c|c|c|c|c|}
\hline Population & $\mathrm{N}$ & G & $H_{\mathrm{E}}(\mathrm{SE})$ & $H_{\mathrm{O}}$ & $F_{\mathrm{IS}}$ & $A$ & $\mathrm{R}_{\mathrm{t}(15)}$ & $p_{\text {gen }}(f)_{\max }$ \\
\hline \multicolumn{9}{|l|}{ Caribbean } \\
\hline 1 Chinchorro & 36 & 26 & $0.725(0.140)$ & 0.724 & 0.001 & 6.2 & 5.7 & $1.4010^{-5}$ \\
\hline 2 Majahual & 36 & 26 & $0.702(0.174)$ & 0.712 & -0.013 & 6.5 & 5.8 & $3.9010^{-5}$ \\
\hline 3 Punta Allen & 36 & 29 & $0.713(0.108)$ & 0.747 & -0.049 & 6.5 & 5.6 & $1.6610^{-5}$ \\
\hline 4 Cozumel Island & 36 & 27 & $0.635(0.165)$ & 0.599 & 0.059 & 5.2 & 4.7 & $1.1910^{-4}$ \\
\hline 5 Puerto Morelos & 35 & 28 & $0.549(0.221)$ & 0.506 & $0.080^{*}$ & 5.8 & 5.1 & $7.8010^{-4}$ \\
\hline 6 Río Nizuc & 36 & 15 & $0.656(0.143)$ & 0.726 & -0.081 & 5.2 & 5.2 & $6.1310^{-5}$ \\
\hline 7 Punta Sam & 36 & 23 & $0.638(0.188)$ & 0.667 & -0.047 & 6.0 & 5.6 & $1.4110^{-4}$ \\
\hline 8 Isla Mujeres & 35 & 25 & $0.684(0.170)$ & 0.727 & -0.064 & 5.7 & 5.2 & $4.5310^{-5}$ \\
\hline \multicolumn{9}{|l|}{ Gulf of Mexico } \\
\hline 9 Ría Lagartos & 36 & 10 & $0.730(0.146)$ & 0.683 & 0.067 & 5.8 & - & $5.6310^{-5}$ \\
\hline 10 Chabihau & 36 & 16 & $0.697(0.098)$ & 0.792 & $-0.141^{*}$ & 5.3 & 5.3 & $3.2110^{-4}$ \\
\hline 11 Alacranes-IP & 36 & 25 & $0.582(0.090)$ & 0.613 & -0.055 & 4.0 & 3.7 & $5.5510^{-4}$ \\
\hline 12 Alacranes-ID & 36 & 19 & $0.668(0.147)$ & 0.614 & 0.083 & 5.2 & 5.0 & $1.2210^{-4}$ \\
\hline 13 Celestún & 36 & 4 & $0.738(0.079)$ & 0.833 & -0.154 & 3.8 & - & $5.2410^{-4}$ \\
\hline 14 Ciudad del Sol & 35 & 17 & $0.638(0.224)$ & 0.637 & 0.002 & 5.2 & 5.0 & $5.8210^{-5}$ \\
\hline 15 Terminos Lagoon & 36 & 10 & $0.611(0.109)$ & 0.650 & -0.067 & 3.3 & - & $1.8610^{-3}$ \\
\hline 16 Veracruz & 36 & 19 & $0.602(0.133)$ & 0.614 & -0.021 & 4.7 & 4.5 & $1.1310^{-3}$ \\
\hline
\end{tabular}


Table 4. Thalassia testudinum. Probability of membership of the populations to the 3 clusters $(K=3)$ determined with STRUCTURE v. 2.1 (Pritchard \& Wen 2003). Numbers in bold indicate highest assignment probability, and are used for the genetic clusters in Fig. 1. Alacranes-IP: Isla Pérez; Alacranes-ID: Isla Desterrada

\begin{tabular}{|lccc|}
\hline Population & \multicolumn{3}{c|}{ Inferred clusters } \\
& 1 & 2 & 3 \\
\hline 1 Chinchorro & $\mathbf{0 . 5 7 3}$ & 0.230 & 0.197 \\
2 Majahual & 0.298 & $\mathbf{0 . 5 2 2}$ & 0.180 \\
3 Punta Allen & $\mathbf{0 . 4 2 0}$ & 0.391 & 0.189 \\
4 Cozumel Island & 0.353 & $\mathbf{0 . 3 6 4}$ & 0.283 \\
5 Puerto Morelos & $\mathbf{0 . 6 4 3}$ & 0.201 & 0.156 \\
6 Río Nizuc & $\mathbf{0 . 4 8 8}$ & 0.084 & 0.428 \\
7 Punta Sam & $\mathbf{0 . 5 3 7}$ & 0.120 & 0.344 \\
8 Isla Mujeres & $\mathbf{0 . 4 4 8}$ & 0.168 & 0.383 \\
9 Ría Lagartos & $\mathbf{0 . 4 2 1}$ & 0.283 & 0.296 \\
10 Chabihau & 0.324 & $\mathbf{0 . 4 0 3}$ & 0.274 \\
11 Alacranes IP & 0.075 & $\mathbf{0 . 8 2 7}$ & 0.098 \\
12 Alacranes ID & 0.162 & $\mathbf{0 . 6 3 4}$ & 0.205 \\
13 Celestún & 0.212 & 0.195 & $\mathbf{0 . 5 9 3}$ \\
14 Ciudad del Sol & 0.278 & 0.140 & $\mathbf{0 . 5 8 2}$ \\
15 Terminos Lagoon & 0.061 & 0.082 & $\mathbf{0 . 8 5 7}$ \\
16 Veracruz & 0.088 & 0.196 & $\mathbf{0 . 7 1 6}$ \\
& & & \\
\hline
\end{tabular}

within the bed of origin. Jiménez Durán (2004) reported that seeds liberated within the bed of origin had a very limited dispersal (1 to several meters). The high seed retention of $T$. testudinum in the Mexican populations in the present study is reflected by low values of recent migration between populations. The Bayesian assignment test showed that the proportion of recently established immigrants (direct or $\mathrm{F}_{1}$ of migrants with non-migrants) was low, and 68 to $99 \%$ of the individuals were assigned to their own population (Table 5). Thus, recombination of genotypes within populations

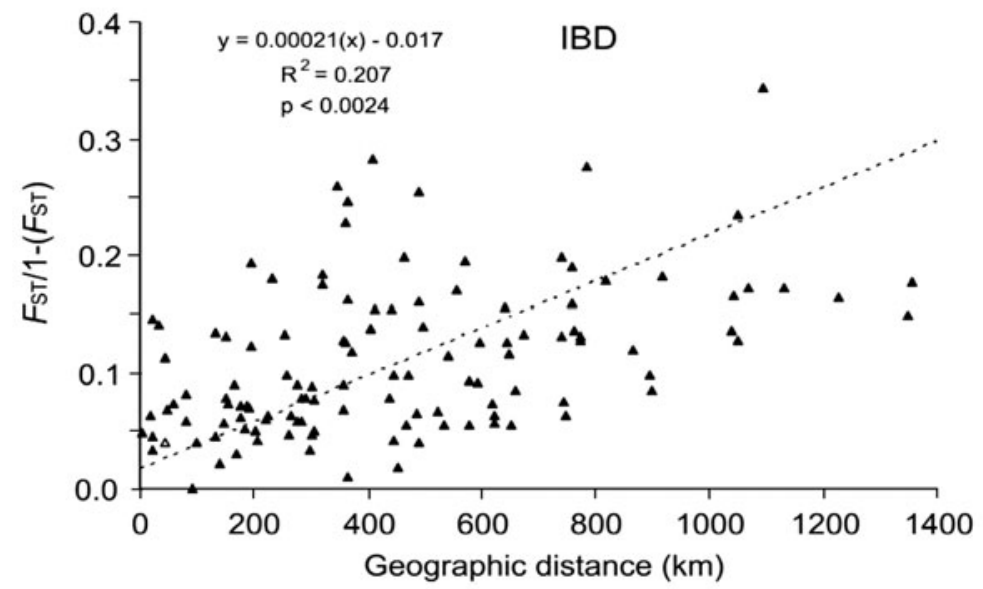

Fig. 5. Thalassia testudinum. Isolation by distance (IBD) for 16 Mexican populations along the Atlantic coast, determined with the use of a Mantel test (Bohonak 2002). $F_{\mathrm{ST}}$ : degree of genetic differentiation among pairs of populations. The slope, correlation coefficient and p-value were deduced with a reduced major axis regression is the most likely mechanism for achieving and maintaining local genetic variability. A limited rate of recent migrations does not necessarily imply low genetic connectivity between populations, as low export and import rates of propagules can prevent differentiation between distinct populations (Procaccini et al. 2007).

The transport over larger distances of the fruits which floated to the surface was primarily caused by the direction and speed of surface currents. In the Puerto Morelos reef lagoon, the relationship between current speed and the rate of displacement of the fruit models was almost linear, whereas the wind transferred only $\sim 10 \%$ of its speed to these models (Table 2, Fig. 2). The discrepancy in direction between the actual wind and the wind-effect on the displacement of the models (Fig. 3) might be attributed to the effect of waves. On calm days, the floating fruits in the Puerto Morelos reef lagoon traveled at a mean velocity of 395 $\mathrm{m} \mathrm{h}^{-1}$. Considering that $65 \%$ of these fruits opened within $1 \mathrm{~d}$, their traveling distance was $9.5 \mathrm{~km}$ at most. The maximum recorded flotation time of the fruits was $10 \mathrm{~d}$, and at latter velocity this could result in a potential dispersal of $\sim 95 \mathrm{~km}$ within the lagoon system (Fig. 4), but within $1 \mathrm{~d}$, the fruits would most likely either have stranded or have been picked up by a faster coastal current. During one of our fruit dispersal trials (starting point $\sim 100 \mathrm{~m}$ from the reef tract), the released fruit models disappeared from the reef lagoon after $30 \mathrm{~min}$, crossing the reef crest into the open sea. This suggests that diffusion into the open sea and incorporation of the fruits into the faster coastal currents is not unlikely, suggesting that even higher dispersal rates should be considered. The direction and velocity of surface coastal transport (seaward side of the coastal lagoon) in this region were determined by Merino Ibarra (1986) by recapture of beached, neutrally buoyant drifting cards released outside the reef near Puerto Morelos in the month of October, one of the months with major fruiting incidence. Along the Yucatan Peninsula, these drifting cards principally traveled at minimum velocities of 0.2 to $3.0 \mathrm{~km} \mathrm{~h}^{-1}$ (mean velocity $1.5 \mathrm{~km} \mathrm{~h}^{-1}$ ) parallel to the coastline (S-N and N-S), with a tendency to drift ashore. Thus bidirectional transport of the floating fruits along the Caribbean coastline of the Yucatan Peninsula is a likely scenario, which is corroborated by the absence of clear directional gene flow in the Bayesian assignment test (Table 5). If we consider bidirectional transport, the resulting maximum dispersal potential of the Thalassia testudinum floating fruits is between $\sim 190$ and $720 \mathrm{~km}$ (corresponding to a drifting period of $10 \mathrm{~d}$ within and outside the reef lagoon, respec- 
Table 5. Migration values of Thalassia testudinum according to the Bayesian assignment test implemented in BayesAss (Wilson \& Rannala 2003). The values represent the estimated percentage of individual that migrated into each population from one of the 16 sampled populations along the Mexican Atlantic coast. Bold numbers represent the representative migration values (>5\%)

\begin{tabular}{|c|c|c|c|c|c|c|c|c|c|c|c|c|c|c|c|c|}
\hline \multicolumn{17}{|c|}{ From population } \\
\hline & 1 & 2 & 3 & 4 & 5 & 6 & 7 & 8 & 9 & 10 & 11 & 12 & 13 & 14 & 15 & 16 \\
\hline 1 & 96.9 & 0.3 & 0.2 & 0.2 & 0.3 & 0.1 & 0.2 & 0.2 & 0.1 & 0.3 & 0.4 & 0.1 & 0.2 & 0.2 & 0.1 & 0.1 \\
\hline 2 & 0.2 & 97.8 & 0.1 & 0.1 & 0.2 & 0.1 & 0.2 & 0.1 & 0.1 & 0.2 & 0.2 & 0.2 & 0.1 & 0.1 & 0.1 & 0.1 \\
\hline 3 & 0.9 & 2.6 & 68.0 & 0.4 & 1.0 & 0.3 & 1.1 & 0.4 & 0.4 & 22.6 & 0.6 & 0.4 & 0.3 & 0.4 & 0.3 & 0.3 \\
\hline 4 & 0.5 & 0.8 & 0.4 & 68.6 & 1.1 & 0.4 & 5.8 & 0.4 & 0.4 & 13.5 & 6.0 & 0.4 & 0.4 & 0.7 & 0.4 & 0.4 \\
\hline 5 & 0.2 & 0.1 & 0.1 & 0.1 & 98.0 & 0.1 & 0.2 & 0.1 & 0.1 & 0.1 & 0.1 & 0.1 & 0.1 & 0.1 & 0.1 & 0.1 \\
\hline 6 & 0.9 & 0.7 & 0.7 & 0.7 & 4.2 & 68.6 & 15.2 & 0.7 & 0.7 & 0.9 & 0.7 & 0.7 & 0.7 & 3.4 & 0.6 & 0.6 \\
\hline 7 & 0.2 & 0.1 & 0.1 & 0.1 & 0.2 & 0.1 & 97.8 & 0.2 & 0.1 & 0.2 & 0.1 & 0.1 & 0.1 & 0.1 & 0.1 & 0.1 \\
\hline 8 & 1.1 & 0.7 & 0.5 & 0.5 & 17.3 & 0.4 & 3.8 & 68.3 & 0.3 & 3.2 & 0.9 & 0.4 & 0.5 & 1.4 & 0.4 & 0.5 \\
\hline 9 & 1.8 & 1.4 & 1.3 & 1.0 & 1.7 & 0.8 & 4.1 & 1.5 & 70.0 & 8.8 & 2.7 & 0.9 & 0.9 & 1.5 & 0.8 & 1.0 \\
\hline 10 & 0.2 & 0.2 & 0.2 & 0.2 & 0.2 & 0.1 & 0.2 & 0.2 & 0.2 & 97.4 & 0.2 & 0.2 & 0.2 & 0.1 & 0.2 & 0.1 \\
\hline 11 & 0.1 & 0.1 & 0.1 & 0.1 & 0.1 & 0.1 & 0.1 & 0.1 & 0.1 & 0.1 & 98.6 & 0.1 & 0.1 & 0.1 & 0.1 & 0.1 \\
\hline 12 & 1.1 & 1.0 & 0.8 & 0.7 & 2.7 & 0.5 & 2.2 & 0.7 & 0.5 & 6.0 & 11.1 & 69.2 & 0.6 & 1.7 & 0.5 & 0.5 \\
\hline 13 & 1.7 & 1.6 & 1.3 & 1.4 & 2.8 & 1.3 & 3.0 & 1.6 & 1.2 & 2.5 & 1.8 & 1.5 & 72.5 & 3.4 & 1.2 & 1.4 \\
\hline 14 & 0.2 & 0.2 & 0.2 & 0.2 & 0.2 & 0.1 & 0.2 & 0.2 & 0.1 & 0.2 & 0.1 & 0.2 & 0.1 & 97.6 & 0.1 & 0.2 \\
\hline 15 & 1.0 & 1.0 & 1.0 & 1.1 & 1.0 & 0.9 & 1.0 & 1.7 & 1.1 & 1.0 & 1.0 & 1.0 & 1.0 & 15.5 & 69.7 & 1.0 \\
\hline 16 & 0.1 & 0.1 & 0.1 & 0.1 & 0.1 & 0.1 & 0.1 & 0.1 & 0.1 & 0.1 & 0.1 & 0.1 & 0.1 & 0.1 & 0.1 & 98.3 \\
\hline
\end{tabular}

tively; Fig. 4), which coincides reasonably well with the above-mentioned area of genetic panmixis of 350 $\mathrm{km}$. The maximal coastal dispersal potential of floating fruits of $T$. testudinum along the Mexican coasts far exceeded the estimated dispersal range of the floating fruits and seeds of the same species in Laguna Madre, Texas (<1.5 to $15 \mathrm{~km}$, Kaldy \& Dunton 1999), and the recorded displacement of floating fruits of $T$. hemprichii $(74 \mathrm{~km})$ and Enhalus arcoroides $(64 \mathrm{~km})$ in the Philippines (Lacap et al. 2002). Other plant species that share a similar 2-dimensional marine dispersal strategy are mangroves, with estimated dispersal ranges of viviparous propagules of up to $50 \mathrm{~km}$ for $A v i$ cennia marina (Clarke 1993). Kinlan \& Gaines (2003) estimated maximum mean dispersal in marine organisms from the slopes of IBD graphs, and if we apply their procedure to the IBD graph of $T$. testudinum, the maximum mean genetic dispersal distance would be $7.7 \mathrm{~km}$, which fits reasonably well with the abovementioned range of dispersal (maximum $9.5 \mathrm{~km}$ ) of the majority $(65 \%)$ of the floating fruits which opened within $1 \mathrm{~d}$.

In conclusion, our results of population genetic structure and connectivity were concordant with the estimates of fruit dispersal, and indicated that the marine angiosperm Thalassia testudinum has the potential to disperse seeds over a large range of distances (1 to $10^{5} \mathrm{~m}$ ) along the Mexican tropical Atlantic coast. The dual dispersal strategy (seed release before or after fruit detachment) allowed for high within-population recombination and seed retention combined with the export of genes over large distances, resulting in a highly leptokurtic dispersal curve. Considering its habitat and the anatomy of the fruits and seeds, this particular seagrass species must be an obligate longdistance disperser. The seeds lack hard seed coats and do not pass through a stage of dormancy, and hence do not form seed banks (Orpurt \& Boral 1964, van Tussenbroek et al. 2006). But the populations are subject to elimination by potential major natural perturbations such as hurricanes (Creed et al. 2003), and therefore rely on imported seeds for recolonization. Thus high levels of gene flow were expected and found for T. testudinum in the study area. Some other marine angiosperms such as Zostera spp. share such high patterns in gene flow, which differ from those found in freshwater plants. Although freshwater angiosperms typically have high dispersal potentials (by waterfowl, Santamaría 2002, Figuerola et al. 2002 or hydrochory, Merritt \& Wohl 2002), they tend to be distributed in separated water bodies, and therefore generally show higher levels of genetic structuring between populations (De Meester et al. 2002, Santamaría 2002). Seeds from terrestrial angiosperms dispersed by wind travel on the order of 10 to $10^{2} \mathrm{~m}$ (Nathan et al. 2002), but mechanistic models estimated that seed uplifting (which occurred in 1 to $5 \%$ of the cases) may extend the dispersal distance to $10^{3}$ to $10^{4} \mathrm{~m}$ in the case of yellow poplar Liriodendron tulipifera (Nathan et al. 2002), which is still 1 order of magnitude lower than the maximum dispersal reported for T. testudinum. Kinlan \& Gaines (2003), in an extensive review contrasting propagule dispersal in marine and terrestrial environments, concluded that the maximum estimates of terrestrial plant dispersal were 1 or 2 orders of magnitude lower than that of marine sedentary species. Our esti- 
mates of dispersal of the marine angiosperm T. testudinum confirmed this paradigm of openness in the marine environment, emphasizing that marine organisms may exhibit larger dispersal potentials than their terrestrial counterparts.

Acknowledgements. The present study was part of the $\mathrm{PhD}$ project of J.K.V.D. (Programa de Posgrado en Ciencias del Mar y Limnología, UNAM), funded by Instituto de Ciencias del Mar y Limnología (UNAM) and PAPIIT project nos. IN213803, IN-239304 and IN213307 (DGAPA, UNAM). Thanks to G. Barba Santos and D. Gazca Flores for support in the field and laboratory, A. Le Cossec for help with GIS calculations and A. Morales Garcia for collecting samples in Veracruz. F. Ruíz-Rentería and E. Escalante Mancera helped with the design interpretations of the fruit dispersal experiments. Samples were collected with permit no. DGOPA/16992/050106/ 0037 SAGARPA, CONAPESCA.

\section{LITERATURE CITED}

Arnaud-Haond S, Belkhir K (2007) GENCLONE: a computer program to analyze genotypic data, test for clonality and describe spatial clonal organization. Mol Ecol Notes $7: 15-17$

Arnaud-Haond S, Migliaccio M, Diaz-Almeda E, Teixeira S and others (2007) Vicariance patterns in the Mediterranean Sea: east-west cleavage and low dispersal in the endemic seagrass Posidonia oceanica. J Biogeogr 34: 963-976

Bohonak AJ (2002) IBD (isolation by distance): a program for analyses of isolation by distance. J Hered 93:153-154

Buia MC, Mazzella L (1991) Reproductive phenology of the Mediterranean seagrasses Posidonia oceanica (L.) Delile, Cymodocea (Ucria) Aschers., and Zostera noltii Hornem. Aquat Bot 40:343-362

Cain ML, Milligan BG, Strand AE (2000) Long-distance seed dispersal in plant populations. Am J Bot 87:1217-1227

Carr MH, Neigel JE, Estes JA, Andelman S, Warner RR, Largier JL (2003) Comparing marine and terrestrial ecosystems: implications for the design of coastal marine reserves. Ecol Appl 13(Suppl):90-107

> Clarke PJ (1993) Dispersal of grey mangrove (Avicennia marina) propagules in southeastern Australia. Aquat Bot 45:195-204

> Coronado C, Candela J, Iglesias-Prieto R, Sheinbaum J, Lopez M, Ocampo-Torres FJ (2007) On the circulation in the Puerto Morelos fringing reef lagoon. Coral Reefs 26:149-163

Cowen RK, Paris CB, Srinivasan A (2006) Scaling of connectivity in marine populations. Science 311:522-527

> Coyer JA, Diekmann OE, Serrão EA, Procaccini G, Milchakova N, Pearson GA, Olsen JL (2004) Population genetics of dwarf eelgrass Zostera noltii throughout its biogeographic range. Mar Ecol Prog Ser 281:51-62

Creed JC, Phillips RC, van Tussenbroek BI (2003) Seagrasses of the Caribbean. In: Green EP, Short FT (eds) World atlas of seagrasses. Prepared by the UNEP World Conservation Monitoring Centre. University of California Press, Berkeley, CA, p 234-242

> Creste S, Tulmann Neto A, Figueira A (2001) Detection of single sequence repeat polymorphisms in denaturating polyacrylamide sequence gels by silver staining. Plant Mol Biol Rep 19:299-306
De Meester L, Gómez A, Okamura B, Schwenk K (2002) The monopolization hypothesis and the dispersal-gene flow paradox in aquatic organisms. J Ecol 23:121-135

> Dieckmann U, O'Hara B, Weisser W (1999) The evolutionary ecology of dispersal. Trends Ecol Evol 14:88-90

Doyle JJ, Doyle JL (1991) Isolation of plant DNA from fresh tissue. Focus 12:3-5

Evanno G, Regaut S, Goudet J (2005) Detecting the number of clusters of individuals using the software STRUCTURE: a simulation study. Mol Ecol 14:2611-2620

> Excoffier L, Laval G, Schneider S (2005) Arlequin ver. 3.0: an integrated software package for population genetics data analysis. Evol Bioinform Online 1:47-50

> Ferber S, Stam WT, Olsen JL (2008) Genetic diversity and connectivity remain high in eelgrass Zostera marina populations in the Wadden Sea, despite major impacts. Mar Ecol Prog Ser 372:87-96

Figuerola J, Green AJ, Santamaría L (2002) Comparative dispersal effectiveness of wigeongrass seeds by waterfowl wintering in south-west Spain: quantitative and qualitative aspects. J Ecol 90:989-1001

Goudet J (1995) FSTAT (version 1.2): a computer program to calculate F-statistics. J Hered 86:485-486

Goudet J (2002) FSTAT: a program to estimate and test gene diversities and fixation indices (version 2.9.3.2). Available at http://www.unil.ch/popgen/softwares/fstat.htm

Guichard F, Levin SA, Hastings A, Siegel D (2004) Toward a dynamic metacommunity approach to marine reserve theory. Bioscience 54:1003-1011

Harwell MC, Orth RJ (2002) Long-distance dispersal potential in a marine macrophyte. Ecology 83:3319-3330

> Hernández-Arana HA, Rodwen AA, Attrill MJ, Warwick RM, Gold-Bouchot G (2003) Large-scale environmental influences on the benthic macroinfauna of the southern Gulf of Mexico. Estuar Coast Shelf Sci 58:825-841

> Ibrahim KM, Nichols RA, Hewitt GM (1996) Spatial patterns of genetic variation generated by different forms of dispersal during range expansion. Heredity 77:282-291

Jiménez Durán K (2004) Desarrollo y dispersión de frutos y semillas e Thalassia testudinum Banks ex König (Hydrocharitaceae). MS thesis, Facultad de Ciencias, Universidad Nacional Autónoma de México, Cancún, with English Abstract

Kaldy JE, Dunton KH (1999) Ontogenic photosynthetic changes, dispersal and survival of Thalassia testudinum (turtle grass) seedlings in a sub-tropical lagoon. J Exp Mar Biol Ecol 240:193-212

> Kalinowski ST (2005) HP-RARE 1.0: a computer program for performing rarefaction on measures of allelic richness. Mol Ecol 5:187-189

Källström B, Nyqvist A, Åberg P, Bodin M, André C (2008) Seed rafting as a dispersal strategy for eelgrass (Zostera marina). Aquat Bot 88:148-153

> Kinlan BP, Gaines SD (2003) Propagule dispersal in marine and terrestrial environments: a community perspective. Ecology 84:2007-2020

> Kinlan BP, Gaines SD, Lester SE (2005) Propagule dispersal and the scales of marine community process. Divers Distrib 11:139-148

Kirsten JH, Dawes CJ, Cochrane BJ (1998) Randomly amplified polymorphism detection (RAPD) reveals high genetic diversity in Thalassia testudinum banks ex König (turtlegrass). Aquat Bot 61:269-287

> Lacap CDA, Vermaat JE, Rollon RN, Nacorda HM (2002) Propagule dispersal of the SE Asian seagrasses Enhalus acoroides and Thalassia hemprichii. Mar Ecol Prog Ser 235:75-80 
Largier JL (2003) Considerations in estimating larval dispersal distances from oceanographic data. Ecol Appl 13:71-89

Larkin P, Quevedo E, Salinas S, Parker J, Storey K, Hardegree B (2006) Genetic structure of two Thalassia testudinum populations from the south Texas Gulf Coast. Aquat Bot 85:198-202

Leslie H, Ruckelshaus M, Ball IR, Andelman S, Possingham HP (2003) Using siting algorithms in the design of marine reserve networks. Ecol Appl 13(Suppl):185-198

Maguire TL, Saenger P, Baverstock P, Henry R (2000) Microsatellite analysis of genetic structure in the mangrove species Avicennia marina (Forsk.) Vierh. (Avicenniaceae). Mol Ecol 9:1853-1862

Merino Ibarra M (1986) Aspectos de la circulación costera superficial del Caribe Mexicano con base en observaciones utilizando tarjetas de deriva. An Inst Cienc Mar Limnol Univ Nac Auton Mex 13:31-46 (with English Abstract)

Merritt DM, Wohl EE (2002) Processes governing hydrochory along rivers: hydraulics, hydrology, and dispersal phenology. Ecol Appl 12:1071-1087

Muñiz-Salazar R, Talbot SL, Sage GK, Ward DH, CabelloPasini A (2005) Population genetic structure of annual and perennial populations of Zostera marina L. along the Pacific coast of Baja California and the Gulf of California. Mol Ecol 14:711-722

Nathan R, Muller-Landau HC (2000) Spatial patterns of seed dispersal, their determinants and consequences for recruitment. Trends Ecol Evol 15:278-285

Nathan R, Katul GG, Horn HS, Thomas SM and others (2002) Mechanisms of long-distance dispersal of seeds by wind. Nature 418:409-413

Nei M (1973) Analysis of gene diversity in subdivided populations. Proc Natl Acad Sci USA 70:3321-3323

Núñez-Farfán J, Domíguez CA, Eguiarte LE, Cornejo A, Quijano M, Vargas J, Dirzo R (2002) Genetic divergence among Mexican populations of red mangrove (Rhizophora mangle): geographic and historic effects. Evol Ecol Res 4:1049-1064

Olsen JL, Stam WT, Coyer JA, Reusch TBH and others (2004) North Atlantic phylogeography and large-scale population differentiation of the seagrass Zostera marina L. Mol Ecol 13:1923-1941

Onuf CP, Phillips JC, Moncreiff CA, Raz-Guzman A, HerreraSilveira JA (2003) The seagrasses of the Gulf of Mexico. In: Green E, Short F (eds) World atlas of seagrasses. Prepared by the UNEP World Conservation Monitoring Centre. University of California Press, Berkeley, CA, p 224-233

Orpurt PA, Boral LL (1964) The flower, fruits, and seeds of Thalassia testudinum Koenig. Bull Mar Sci 14:296-302

Orth RJ, Harwell MC, Inglis GJ (2006) Ecology of seagrasses seeds and dispersal strategies. In: Larkum AWD, Orth RJ, Duarte CM (eds) Seagrasses: biology, ecology and conservation. Springer, Dordrecht, p 111-133

Palumbi SR (2003) Population genetics, demographic connectivity, and the design of marine reserves. Ecol Appl 13(Suppl):146-158

Parks JC, Werth CR (1993) A study of spatial features of clones in population of bracken fern, Pteridium aquilinum
(Dennstaedtiaceae). Am J Bot 80:537-544

Pritchard JK, Wen W (2003) Documentation for STRUCTURE software: version 2. Available at http://pritch.bsd.uchicago. edu/software/readme_2_1/readme.html

Procaccini G, Olsen JL, Reusch TBH (2007) Contribution of genetics and genomics to seagrass biology and conservation. J Exp Mar Biol Ecol 350:234-259

Raymond M, Rousset F (1995) GENEPOP (version 3.4): population genetics software for exact tests and ecumenicism. J Hered 86:248-249

Reusch TBH (2002) Microsatellites reveal high population connectivity in eelgrass (Zostera marina) in two contrasting coastal areas. Limnol Oceanogr 47:78-85

> Roughgarden J, Gaines SD, Possingham H (1988) Recruitment dynamics in complex life cycles. Science 241: 1460-1466

Rousset F (1997) Genetic differentiation and estimation of geneflow from F-statistics under isolation by distance. Genetics 145:1219-1228

Ruíz-Rentería F, van Tussenbroek BI, Jordán-Dahlgren E (1998) Puerto Morelos, Quintana Roo, México. In: Kjerfve B (ed) Caribbean coral reef, seagrass and mangrove sites. Coastal Region and Small Island Papers 3, UNESCO, Paris, p 57-66

Santamaría L (2002) Why are most aquatic plants widely distributed? Dispersal, clonal growth and small-scale heterogeneity in a stressful environment. Acta Oecol 23:137-154

Shanks AL, Grantham BA, Carr MH (2003) Propagule dispersal distance and the size and spacing of marine reserves. Ecol Appl 13:159-169

Siegel DA, Kinlan BP, Gaylord B, Gaines SD (2003) Lagrangian descriptions of marine larval dispersion. Mar Ecol Prog Ser 260:83-96

van Dijk JK, Waycott M, Van Tussenbroek BI, Ouborg J (2007) Polymorphic microsatellite markers for the Caribbean seagrass Thalassia testudinum Banks ex König. Mol Ecol Notes 7:89-91

van Tussenbroek BI (1995) Thalassia testudinum leaf dynamics in a Mexican Caribbean coral reef lagoon. Mar Biol 122:33-40

van Tussenbroek BI, Vonk JA, Stapel J, Erftemeijer PLA, Middelburg JJ, Zieman JC (2006) The biology of Thalassia: paradigms and recent advances in research. In: Larkum AWD, Orth RJ, Duarte CM (eds) Seagrasses: biology, ecology and conservation. Springer, Dordrecht, p 409-439

- Waycott M, Barnes PAG (2001) AFLP diversity within and between populations of the Caribbean seagrass Thalassia testudinum (Hydrocharitaceae). Mar Biol 139:1021-1028

Waycott M, Procaccini G, Les DH, Reusch TBH (2006) Seagrass evolution, ecology and conservation: a genetic perspective. In: Larkum AWD, Orth RJ, Duarte CM (eds) Seagrasses: biology, ecology and conservation. Springer, Dordrecht, p 25-50

> Weir BS, Cockerham CC (1984) Estimating F-statistics for the analysis of population structure. Evolution 38:1358-1370

> Wilson GA, Rannala B (2003) Bayesian inference of recent migration rates using multilocus genotypes. Genetics 163: $1177-1191$

Submitted: January 29, 2009; Accepted: June 26, 2009

Proofs received from author(s): September 1, 2009
Editorial responsibility: Richard Osman,

Edgewater, Maryland, USA 